\title{
Progressive retinal vessel malformation in a premature infant with Sturge-Weber syndrome: a case report and a literature review of ocular manifestations in Sturge- Weber syndrome
}

\author{
Zhengping $\mathrm{Hu}^{1,2}$, Jian $\mathrm{CaO}^{3,4}$, Eun Young Choi ${ }^{1,2}$ and $\mathrm{Yun} \mathrm{Li}^{3,4^{*}}$ (1)
}

\begin{abstract}
Background: Sturge-Weber syndrome is a disorder marked by a distinctive facial capillary malformation, neurological abnormalities, and ocular abnormalities such as glaucoma and choroidal hemangioma.

Case presentation: We report a case of progressively formed retinal vessel malformation in a premature male infant with Sturge-Weber syndrome and retinopathy of prematurity, after treatment with intravitreal anti-vascular endothelial growth factor (VEGF). The baby was born at 30 weeks gestation with a nevus flammeus involving his left eyelids and maxillary area. On postmenstrual age week 39, he received intravitreal anti-VEGF. Diffuse choroidal hemangioma became evident at 40 weeks, with the classic "tomato catsup fundus" appearance. These clinical findings characterized Sturge-weber syndrome. He presented with posterior retinal vessel tortuosity and vein-tovein anastomoses at 44 weeks.
\end{abstract}

Conclusion: This is a rare case of documented progression of retinal vessel malformations in a patient with SturgeWeber syndrome and retinopathy of prematurity.

Keywords: Sturge-weber syndrome, Ocular manifestation, Retinal vessel malformation, Nevus flammeus, Diffuse choroidal hemangioma

\section{Background}

Sturge-Weber syndrome (SWS) is a rare congenital phakomatosis defined by several vascular anomalies, including facial capillary malformations (nevus flammeus) and ipsilateral leptomeningeal angiomatosis, as well as ocular abnormalities which can involve the eyelid, bulbar conjunctiva, cornea, anterior chamber, choroid, and retina,

\footnotetext{
* Correspondence: yun.li@csu.edu.cn

${ }^{3}$ Department of Ophthalmology, The 2nd Xiangya Hospital of Central South University, Changsha, Hunan, People's Republic of China

${ }^{4}$ Hunan Clinical Research Center of Ophthalmic Disease, Changsha, Hunan, People's Republic of China

Full list of author information is available at the end of the article
}

mostly ipsilateral to the nevus flammeus [1, 2]. Infants with hemifacial and forehead nevus flammeus phenotypes are at the highest risk of SWS (45-80\%) [3]. The estimated incidence of SWS is 1:50,000 live births, with no significant difference between males and females [4]. A somatic mutation in the GNAQ gene has been reported to be associated with the pathogenesis of SWS [5].

The spectrum of SWS is classified as follows: Type I is the most common presentation that involves both facial and leptomeningeal angiomas and glaucoma may be present. Type II involves facial angioma (without the involvement of the central nervous system) and may

(c) The Author(s). 2021 Open Access This article is licensed under a Creative Commons Attribution 4.0 International License, which permits use, sharing, adaptation, distribution and reproduction in any medium or format, as long as you give appropriate credit to the original author(s) and the source, provide a link to the Creative Commons licence, and indicate if changes were made. The images or other third party material in this article are included in the article's Creative Commons licence, unless indicated otherwise in a credit line to the material. If material is not included in the article's Creative Commons licence and your intended use is not permitted by statutory regulation or exceeds the permitted use, you will need to obtain permission directly from the copyright holder. To view a copy of this licence, visit http://creativecommons.org/licenses/by/4.0/ The Creative Commons Public Domain Dedication waiver (http://creativecommons.org/publicdomain/zero/1.0/) applies to the data made available in this article, unless otherwise stated in a credit line to the data. 
include glaucoma. Type III is characterized by leptomeningeal angiomas only, with no facial involvement, and glaucoma is rarely seen. The case presented in this report was classified as SWS Type II [6]..

\section{Case presentation}

A premature male infant (gestational age 30 weeks, birth weight $1410 \mathrm{~g}$ ) was screened for retinopathy of prematurity (ROP). The baby was naturally delivered, with a short time of oxygen inhalation after birth. On examination, at age postmenstrual age (PMA) 34 weeks (initial visit) a nevus flammeus was noted on his left eyelids and maxillary area, following the V1 and V2 distributions of the trigeminal nerve (Fig. 1a). From PMA 37 weeks, he was found to have progressive ROP (Zone 2 stage 3 ) in his left eye and received intravitreal ranibizumab (Lucentis, Novartis) at PMA 39 weeks to treat type 1 ROP. Informed consent was obtained from the parents to use ranibizumab to treat the ROP. The ridge and neovascularization regressed satisfactorily, but diffuse choroidal hemangioma (DCH) became evident at 40 weeks, with the classic "tomato catsup fundus" appearance. These clinical findings characterized Sturge-Weber syndrome. At PMA 44weeks, the baby was noted to have increased bulbar conjunctival vascularization and retinal vascular tortuosity. Retcam images showed vein-to- vein anastomoses in the peripheral retina (Fig. 2). Retinal vascular tortuosity and vein-to-vein anastomoses were better appreciated on fundus fluorescein angiography (FFA) under general anesthesia (Fig. 3). The patient continues to have a normal IOP and is under close observation for further ocular changes. Retcam revealed conjunctiva vasodilation in the left eye; no other changes were identified in the anterior chamber. The right eye was normal upon examination. Magnetic resonance imaging did not show leptomeningeal angiomatosis (result not shown).

\section{Discussion and conclusions}

Ocular alterations in SWS are seen in approximately 30$60 \%$ of patients [7]. The vascular anomalies include the facial nevus flammeus $[1,2]$, ipsilateral leptomeningeal angiomatosis [8], diffuse choroidal hemangioma [9-29], and rarely retinal vascular anomalies [30,31]. The GNAQ gene, involved in regulating intracellular signaling pathways [32], has been identified as a potential cause for SWS [5]. Bichsel et al. reported recently that SWS patients have a high GNAQ R183Q mutant allelic frequency, which was comparable to brain tissue from a different set of patients with SWS. Three common somatic mutations of GNAQ were not detected in the patient's choroidal hemangioma tissue in their study [33]. On the other hand, Huang reported that somatic GNAQ p.R183Q mutation is enriched in endothelial cells in SWS brain lesions [34]. Nakashima further confirmed the somatic GNAQ mutation c.548G >A (p.R183Q) in SWS patients [35].

SWS can be found coexisting with other rare phakomatoses or vessel malformations like Klippel-Trenaunay syndrome [36], Wyburn Mason Syndrome [37], and Moyamoya disease [38].

To summarize the ocular manifestations in SWS, we performed a literature search of papers dated from Jan. 1, 1990 to Feb. 28, 2019, using "Sturge-Weber syndrome", "Sturge-Weber and eye", "Sturge-Weber and ocular", "Sturge-Weber and retinal" and "Sturge-weber and glaucoma" as keywords in the PubMed database. The content of each paper was thoroughly checked to ensure its relevance to the topic. Cases in English were checked by the full text. Papers in non-English related to SWS were checked by their English title and abstract. Cases concerning SWS ocular complications were recorded and analyzed.

PubMed search yielded 123 cases diagnosed with "Sturge-Weber syndrome". Among these, 89 (69.6\%) cases with ocular involvement were included. Cases of SWS with ocular trauma and SWS in association with other diseases that may have ocular involvement were excluded. Of the 89 cases, 40 (44.94\%) were female and 49 (55.05\%) were male. The patients' ages ranged from 2 weeks to 66 years old (mean 20.65 years). Ocular complications observed in SWS are diverse and summarized
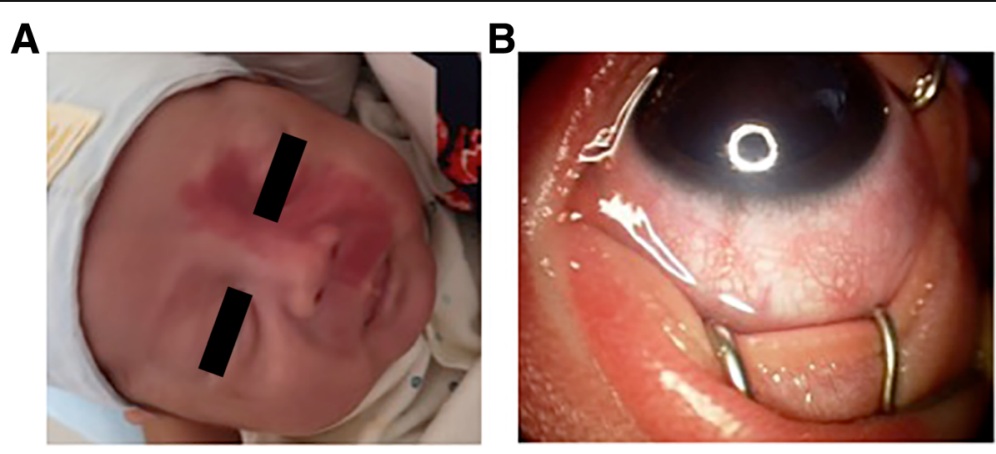

Fig. 1 Vascular abnormalities of the face and anterior segment in a patient with Sturge Weber syndrome. a Nevus flammeus on the left side of the face. $\mathbf{b}$ Retcam image, showing increased epibulbar and conjunctival vasculature in the left eye 


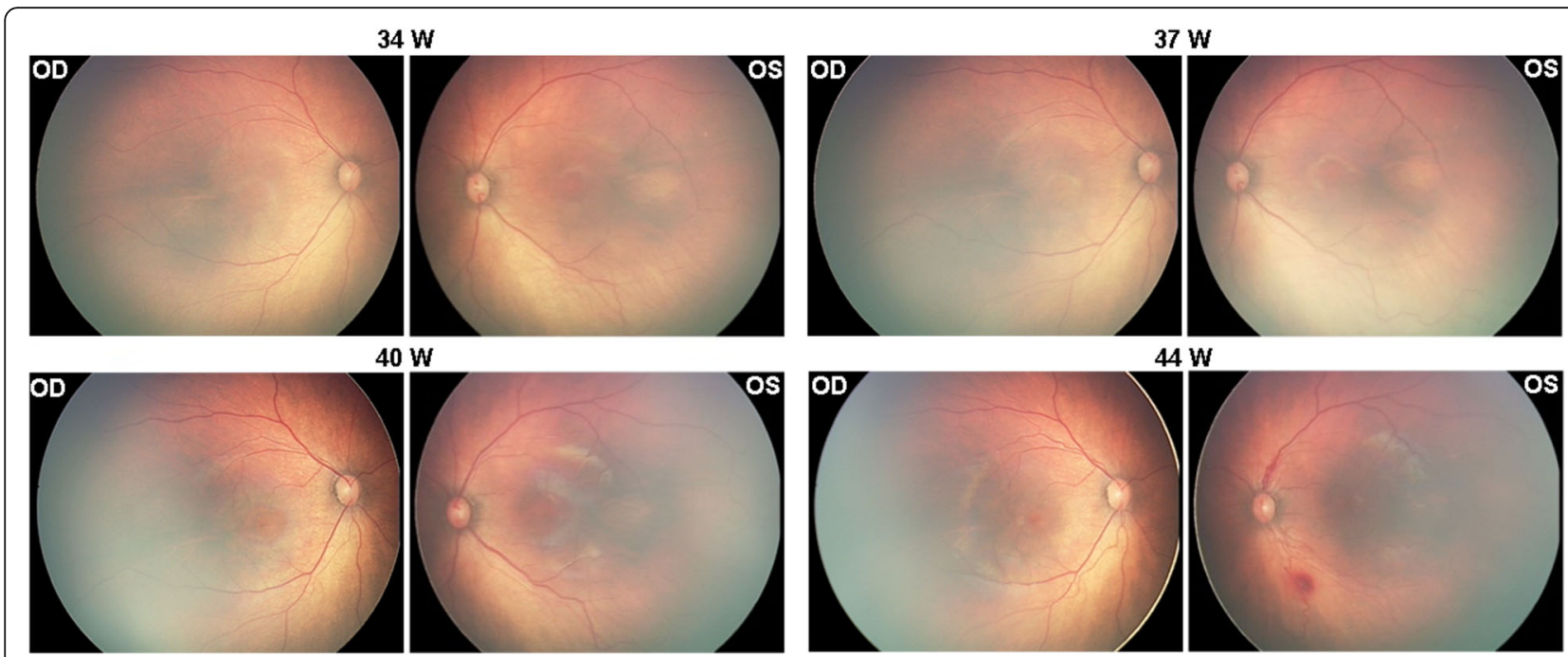

Fig. 2 Progression of the "tomato catsup fundus". Retcam funduscopy images showing progression of the"tomato-catsup fundus" in a patient with Sturge-Weber syndrome and ROP. The images show the gradual formation of a bright reddish color of the fundus (tomato catsup fundus) in the affected left eye compared to the healthy right eye from PMA 34 week to 40 week, which is the characteristic sign of DCH

in Table 1. Cataract and other changes secondary to glaucoma, only glaucoma was recorded.

$\mathrm{DCH}$ was the most common ocular complication associated with SWS, seen in $40.45 \%$ of patients in our literature review [3-11,30-68]. In addition to the typical characteristics of $\mathrm{DCH}$, an early sign could be unilateral anisometropia due to DCH [55]. There were 4 cases of circumscribed choroidal hemangioma in SWS patients. Althaus et al. [73] documented a contralateral circumscribed choroidal hemangioma; the patient had a leftsided naevus flammeus and a right-sided circumscribed choroidal hemangioma. Complications of DCH are macular edema, exudative retinal detachment, pigmentary changes within the RPE, subretinal fibrosis, and orange pigment changes secondary to diffuse choroidal hemangioma [10]. DCH can also be associated with increased choroidal thickness in the fellow eye with no visible hamangioma [76, 77]. Spectral domain optical coherence tomography (SD-OCT) has shown that choroidal thickness of the affected eyes, ipsilateral to facial naevus flammeus, is twice that of the fellow eyes [10]. Chavala et al. reported a patient with a bilateral facial nevus flammeus who developed exudative retinal detachments in both eyes without mentioning the diffuse choroidal hemaniogma [80]. A case of unique subretinal osseous metaplasia in SWS with endophthalmitis, glaucoma and complicated cataract was reported by Pavlenko et al [39]

Glaucoma is another frequent ophthalmic complication of SWS, occurring in $43.82 \%$ of all cases [9, 30, 31, 38-68]. It can be further classified into early-onset glaucoma and late-onset juvenile glaucoma. The proposed
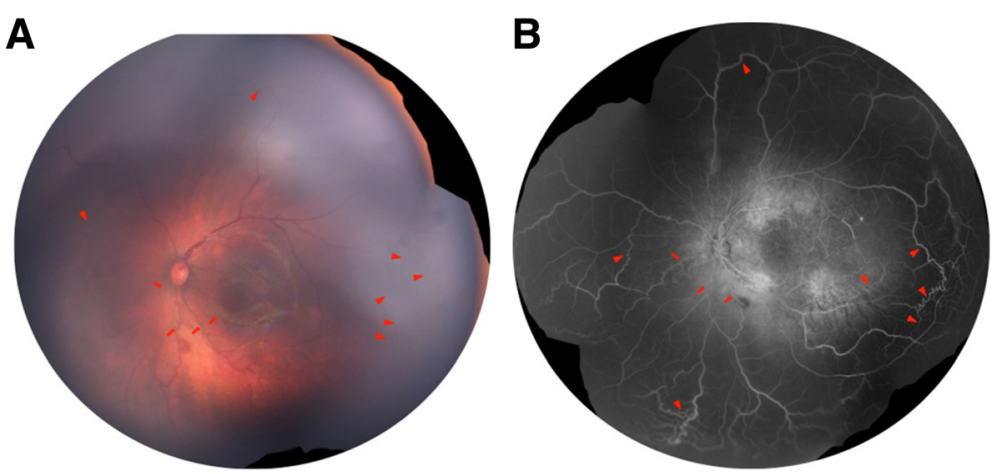

Fig. 3 Fundus photograph and fundus fluorescein angiography (FFA) of the left eye a Fundua photograph and b FFA showed striking tortuosity of posterior retinal vessels (arrows) and multiple vein-to-vein anastomoses (arrowheads) at the periphery, which is better appreciated in FFA. Marked hyper-fluorescent lesions at the posterior pole on recirculation phase of FFA correspond to DCH. The right eye was normal on both fundoscopy and FFA 
Table 1 Ocular complications in Sturge-Weber syndrome

\begin{tabular}{lll}
\hline Complications & Case (percentage of total) & Reference \\
\hline Glaucoma & $36(40.45 \%)$ & {$[9,10,30,31,39-68]$} \\
Diffuse Choroidal Hemangioma & $39(43.82 \%)$ & {$[10-29,31,47,55,57-60,62,64,69]$} \\
Circumscribed choroidal hemangioma & 4 & {$[70-73]$} \\
Retinal vascular anomaly & 5 & {$[10,11,41,74,75]$} \\
Intraocular osseous metaplasia & 1 & {$[39]$} \\
Ocular Melanocytosis & 1 & {$[11]$} \\
Iris Mammillations, neovascularization, atrophy & 3 & {$[11,68,73]$} \\
Increased Choroidal Thickness & $22(24.72 \%)$ & {$[20,76,77]$} \\
Episcleral hemangioma, vessel malformation & 6 & {$[54,65,67,73,78,79]$} \\
Retinal detachment & 1 & {$[80]$} \\
Eyelid hemangioma & 1 & {$[29]$} \\
Central retinal vein occlusion & 1 & {$[61]$} \\
Ectopia lentis & 1 & {$[81]$} \\
Optic neuropathy & 1 & {$[82]$} \\
\hline
\end{tabular}

etiologies of glaucoma in SWS include buphthalmia, anterior chamber angle mal-development, and raised episcleral venous pressure $[3,83]$. Acute primary angleclosure glaucoma, which is rare in SWS patients, has been reported by $\mathrm{Su}$ [9] and Lambiase et al [40] Other commonly observed anterior segment abnormalities include conjunctival, episcleral, and iris vessel dilation and hemangioma. Corneal changes related to congenital glaucoma can also be seen. Secondary cataract has been reported in many cases; Moore et al. [81] report a case of ectopia lentis associated with angle-closure glaucoma without historical trauma. Iris mammilliations are usually observed when SWS is associated with melanocytosis in the context of phakomatosis pigmentovascularis that can further increase the risk of glaucoma [84].

Retinal vascular anomaly is rare in SWS, but when observed, it is often associated with choroidal hemangiomas. Previously documented anomalies include retinal arteriovenous communications [75], a white appearance of retinal vessels, reduced perfusion of the venous system [74], vein-to-vein anastomoses, and retinal venous dilatation and tortuosity [11, 41]. Two of the reported cases were bilateral [63]. Venous congestion of the left upper venous branch was observed in the left eye of a case with bilateral DCH [10].

We describe a premature infant, the youngest SWS patient ever reported, who presented with a left-sided facial nevus flammeus at birth and progression of multiple ocular vessel malformations. The infant had a normal fundus color at the initial visit. We recorded the development of DCH in the affected eye. The color of the fundus turned orange-red, compared to the healthy eye as we showed in the figure, and gradually revealed the characteristic "tomato catsup" fundus. The progression of retinal vessel tortuosity associated with multiple veinto-vein anastomoses present in SWS patients has rarely been reported. The patient was also diagnosed with progressive ROP in his left eye at PMA 37. ROP is an ocular disease characterized by the onset of vascular abnormalities in the developing retina, in which the premature and incompletely vascularized retinas may be obliterated by stressors, namely, oxygen supply. The abnormal vessels in ROP are usually anarchic, leaky, and excessive, which results in the invasion of the vitreous and involves retina traction and bleeding [85]. From PMA 40 weeks and after, we observed the DCH in the left eye, with retinal vessel tortuosity and vein-to-vein anastomoses, which is not similar to retinal vessel abnormality usually seen in ROP. Furthermore, anti-VEGF has been shown effective in halting ROP progression [86]. In the case reported herein retina traction and neovascularization in ROP regressed satisfactorily, but the retinal vessel tortuosity did not regress.

In conclusion we report a gradual formation of $\mathrm{DCH}$ and retinal vessel malformation in an infant. This suggests that babies born with nevus flammeus should be checked repeatedly instead of one-time screening, especially in premature babies.

\footnotetext{
Abbreviations

SWS: Sturge-Weber syndrome; RPE: Retinal Pigment Epithelial; FFA: Fundus Fluorescein Angiography; IOP: Intraocular Pressure; MRI: Magnetic Resonance Imaging; ROP: Retinopathy of Prematurity; VEGF: Vascular Endothelial Growth Factor; DCH: Diffuse Choroidal Hemangioma; CNV: Choroidal Neovascularization; PMA: Post Menstrual Age; OCT: Optical Coherence Tomography; SD-OCT: Spectral-domain Optical Coherence Tomography
} 


\section{Authors' contributions}

$\mathrm{ZH}$ and $\mathrm{YL}$ drafted the manuscript. Literature review was performed and summarized by ZH. YL and JC collected the clinical data. ZH and EC prepare and review the manuscript. All authors have read and approved the manuscript.

\section{Funding}

Supported in part by the National Natural Science Foundation of China (81300798) and Provincial Natural Science Foundation of Hunan (2018JJ3737). The funding agencies had no role in study design, data collection and analysis, interpretation of data, or writing the manuscript.

\section{Availability of data and materials}

Data and materials are available upon request from the corresponding author at yun.li@csu.edu.cn.

\section{Ethics approval and consent to participate}

Written informed consent was obtained from the parents of the patient, who was below 18 years of age, after the nature and possible consequences of the study were explained. Informed consent was obtained from the parents of the child to report the case and present the photographs.

\section{Consent for publication}

The parents or guardians provided consent for the participant in this study signed written consent forms for the publication of their relevant clinical data. A copy is available to the journal.

\section{Competing interests}

The authors declare that there is no competing interest.

\section{Author details}

'Schepens Eye Research Institute, Mass. Eye and Ear, Boston, MA, USA. ${ }^{2}$ Harvard Medical School, Boston, MA, USA. ${ }^{3}$ Department of Ophthalmology, The 2nd Xiangya Hospital of Central South University, Changsha, Hunan, People's Republic of China. ${ }^{4}$ Hunan Clinical Research Center of Ophthalmic Disease, Changsha, Hunan, People's Republic of China.

Received: 12 August 2019 Accepted: 12 January 2021

Published online: 22 January 2021

\section{References}

1. Comi AM. Advances in Sturge-Weber syndrome. Curr Opin Neurol. 2006; 19(2):124-8.

2. Lo W, Marchuk DA, Ball KL, Juhasz C, Jordan LC, Ewen JB, Comi A, Brain Vascular Malformation Consortium National Sturge-Weber Syndrome, W. Updates and future horizons on the understanding, diagnosis, and treatment of Sturge-Weber syndrome brain involvement. Dev Med Child Neurol. 2012;54(3):214-23.

3. Zallmann M, Leventer RJ, Mackay MT, Ditchfield M, Bekhor PS, Su JC Screening for Sturge-Weber syndrome: a state-of-the-art review. Pediatr Dermatol. 2018:35(1):30-42.

4. Di Rocco C, Tamburrini G. Sturge-Weber syndrome. Child's Nervous Syst. 2006;22(8):909-21.

5. Huang Z, Li Y, Zhao Z, Hu J, Tong X, Chen X, Liu S, Xu X, Tao Y, Wang T, Cheng X, Dai Y, Gui Y, Wu J. GNAQ mutation R183Q as a potential cause of familial Sturge-weber syndrome: a case report. Oncol Lett. 2017;13(4):2665-9.

6. Shaikh SM, Goswami M, Singh S, Singh D. Sturge-Weber syndrome - a case report. J Oral Biol Craniofac Res. 2015:5(1):53-6.

7. Bayoumi NHL, Elsayed EN. Glaucoma in children with facial port wine stain. Eur J Ophthalmol. 2020;30(1):168-74. https://doi.org/10.1177/ 1120672118819668. Epub 2018 Dec 19.

8. Zanzmera P, Patel T, Shah V. Diagnostic dilemma: Sturge-Weber syndrome, without facial nevus. J Neurosci Rural Pract. 2015;6(1):105-7.

9. Su WW. Acute primary angle-closure in Sturge-Weber syndrome. Am J Ophthalmol Case Rep. 2018;10:101-4.

10. Formisano M, Abdolrahimzadeh B, Mollo R, Bruni P, Malagola R, Abdolrahimzadeh S. Bilateral diffuse choroidal hemangioma in Sturge Weber syndrome: a case report highlighting the role of multimodal imaging and a brief review of the literature. J Curr Ophthalmol. 2019;31(2): 242-9.
11. Plateroti AM, Plateroti R, Mollo R, Librando A, Contestabile MT, Fenicia V. Sturge-Weber syndrome associated with monolateral ocular melanocytosis, iris mammillations, and diffuse choroidal haemangioma. Case Rep Ophthalmol. 2017:8(2):375-84.

12. Abdolrahimzadeh S, Parisi F, Mantelli F, Perdicchi A, Scuderi G. Retinal pigment epithelium-photoreceptor layer alterations in a patient with Sturge-Weber syndrome with diffuse choroidal hemangioma. Ophthalmic Genet. 2017;38(6):567-9.

13. Dave T, Dave VP, Shah G, Pappuru RR. Diffuse choroidal hemangioma masquerading as central serous chorioretinopathy treated with oral propranolol. Retin Cases Brief Rep. 2016;10(1):11-4.

14. Thapa R, Shields CL. Oral propranolol therapy for management of exudative retinal detachment from diffuse choroidal hemangioma in Sturge-Weber syndrome. Eur J Ophthalmol. 2013;23(6):922-4.

15. Ang M, Lee SY. Multifocal photodynamic therapy for diffuse choroidal hemangioma. Clin Ophthalmol. 2012;6:1467-9.

16. Giuliari GP, Sadaka A, Cortez MA, Corona A. Presumed Sturge Weber syndrome in a haitian boy: a case of delayed diagnosis. Case Rep Ophthalmol Med. 2012;2012:509693.

17. Huiskamp EA, Muskens RP, Ballast A, Hooymans JM. Diffuse choroidal haemangioma in Sturge-Weber syndrome treated with photodynamic therapy under general anaesthesia. Graefes Arch Clin Exp Ophthalmol. 2005;243(7):727-30.

18. Hussain RN, Jmor F, Damato B, Heimann H. Verteporfin photodynamic therapy for the treatment of choroidal haemangioma associated with Sturge-Weber syndrome. Photodiagnosis Photodyn Ther. 2016;15:143-6.

19. Nugent R, Lee L, Kwan A. Photodynamic therapy for diffuse choroidal hemangioma in a child with Sturge-Weber syndrome. J AAPOS. 2015;19(2):181-3.

20. Anaya-Pava EJ, Saenz-Bocanegra CH, Flores-Trejo A, Castro-Santana NA. Diffuse choroidal hemangioma associated with exudative retinal detachment in a Sturge-Weber syndrome case: photodynamic therapy and intravitreous bevacizumab. Photodiagnosis Photodyn Ther. 2015;12(1):136-9.

21. Shoeibi N, Ahmadieh H, Abrishami M, Poorzand H. Rapid and sustained resolution of serous retinal detachment in Sturge-Weber syndrome after single injection of intravitreal bevacizumab. Ocul Immunol Inflamm. 2011;19(5):358-60.

22. Kubicka-Trzaska A, Kobylarz J, Romanowska-Dixon B. Ruthenium-106 plaque therapy for diffuse choroidal hemangioma in sturge-weber syndrome. Case Rep Ophthalmol Med. 2011;2011:785686.

23. Paulus YM, Jain A, Moshfeghi DM. Resolution of persistent exudative retinal detachment in a case of Sturge-Weber syndrome with anti-VEGF administration. Ocul Immunol Inflamm. 2009:17(4):292-4.

24. Anand R. Photodynamic therapy for diffuse choroidal hemangioma associated with Sturge Weber syndrome. Am J Ophthalmol. 2003;136(4):758-60.

25. Amirikia A, Scott IU, Murray TG. Bilateral diffuse choroidal hemangiomas with unilateral facial nevus flammeus in Sturge-Weber syndrome. Am J Ophthalmol. 2000;130(3):362-4.

26. Packwood EA, Havertape SA, Cruz OA, Mann ES. Visual rehabilitation in a child with diffuse choroidal hemangioma by using aggressive amblyopia therapy with low-dose external beam irradiation. J AAPOS. 2000;4(5):321-2.

27. Murthy R, Hanovaz SG, Naik M, Gopi S, Reddy VA. Ruthenium-106 plaque brachytherapy for the treatment of diffuse choroidal haemangioma in Sturge-Weber syndrome. Indian J Ophthalmol. 2005;53(4):274-5.

28. Singh AD, Rundle PA, Vardy SJ, Rennie IG. Photodynamic therapy of choroidal haemangioma associated with Sturge-Weber syndrome. Eye. 2005;19(3):365-7.

29. Ye JJ, Hu TS, Zhang CF, Wang ZH, Zhou WY. Diagnosis and treatment of Sturge-Weber syndrome associated with retinal detachment. Zhongguo yi xue ke xue yuan xue bao Acta Academiae Medicinae Sinicae. 2001;23(4):408-11.

30. Ceyhan A, Cakan T, Basar H, Bababalim M, Unal N. Anaesthesia for SturgeWeber syndrome. Eur J Anaesthesiol. 1999;16(5):339-41.

31. Taherian K, Anand N. Exudative retinal detachment following deep sclerectomy in Sturge-Weber syndrome. Eye. 2007;21(6):842-3.

32. Shirley MD, Tang H, Gallione C, Baugher JD, Frelin LP, Cohen B, North PE, Marchuk DA, Comi AM, Pevsner J. Sturge-Weber syndrome and port-wine stains caused by somatic mutation in GNAQ. N Engl J Med. 2013;368(21):1971-9.

33. Bichsel CA, Goss J, Alomari M, Alexandrescu S, Robb R, Smith LE, Hochman $\mathrm{M}$, Greene AK, Bischoff J. Association of somatic GNAQ mutation with capillary malformations in a case of choroidal hemangioma. JAMA Ophthalmol. 2019;137(1):91-5.

34. Huang L, Couto JA, Pinto A, Alexandrescu S, Madsen JR, Greene AK, Sahin M. Bischoff J. Somatic GNAQ mutation is enriched in brain endothelial cells in Sturge-Weber syndrome. Pediatr Neurol. 2017;67:59-63. 
35. Nakashima M, Miyajima $M$, Sugano $H$, limura $Y$, Kato $M$, Tsurusaki $Y$, Miyake $\mathrm{N}$, Saitsu H, Arai H, Matsumoto N. The somatic GNAQ mutation c.548G>A (p.R183Q) is consistently found in Sturge-Weber syndrome. J Hum Genet. 2014;59(12):691-3.

36. Sharma P, Arya AV, Azad RV. Unusual retinal manifestation in a combination of Sturge-Weber and Klipplel-Trenaunay syndrome--a case report. Indian J Ophthalmol. 1990;38(4):195-7.

37. Ward JB, Katz NN. Combined phakomatoses: a case report of Sturge-Weber and Wyburn-Mason syndrome occurring in the same individual. Ann Ophthalmol. 1983;15(12):1112-6.

38. Hao Z, Lai X. Sturge-Weber syndrome coexisting with moyamoya disease in the fifth decade: a case report and literature review. Neurologist. 2019;24(1):13-6.

39. Pavlenko D, Scovpen T, Vitovska O. Sturge-Weber syndrome-associated glaucoma and intraocular osseous metaplasia: a unique complicated case. BMJ Case Rep. 2018;2018:bcr2017223983. https://doi.org/10.1136/bcr-2017-223983.

40. Lambiase A, Mantelli F, Mannino G, Recupero SM. An unusual case of acute glaucoma in Sturge-Weber syndrome. Eur J Ophthalmol. 2015;25(6):e103-5.

41. Quan AV, Moore GH, Tsui I. Retinal vein-to-vein anastomoses in SturgeWeber syndrome documented by ultra-widefield fluorescein angiography. J AAPOS. 2015;19(3):270-2.

42. Kowalska-Brocka J, Brocki M, Uczniak S, Uczniak K, Kaszuba A, Jurowski P. Sturge-Weber syndrome type II treated with PDL 595 nm laser. Postepy Dermatol Alergol. 2015;32(1):63-6.

43. Tripathi AK, Kumar V, Dwivedi R, Saimbi CS. Sturge-Weber syndrome: oral and extra-oral manifestations. BMJ Case Rep. 2015;2015:bcr2014207663. https://doi.org/10.1136/bcr-2014-207663.

44. Hassan S, Babiker A, Bashiri FA, Hassan HH, Husseini ME, Salih MA. Sturge-Weber syndrome: continued vigilance is needed. Sudanese J Paediatr. 2015;15(2):63-70.

45. Wong HS, Abdul Rahman R, Choo SY, Yahya N. Sturge-Weber-syndrome with extreme ocular manifestation and rare association of upper airway angioma with anticipated difficult airway. Med J Malaysia. 2012;67(4):435-7.

46. Basler L, Sowka J. Sturge-Weber syndrome and glaucoma. Optometry. 2011; 82(5):306-9.

47. Gambrelle J, Denis P, Kocaba V, Grange JD. Uveal effusion induced by topical travoprost in a patient with Sturge-Weber-Krabbe syndrome. J Fr Ophtalmol. 2008;31(9):e19.

48. Elgin U, Simsek T, Batman A. Use of the ex-press miniature glaucoma implant in a child with Sturge-Weber syndrome. J Pediatr Ophthalmol Strabismus. 2007;44(4):248-50.

49. Georgescu EF, Stanescu L, Dumitrescu D, Ionescu R, Georgescu I. Portal cavernomatous transformation leading to variceal hemorrhage in SturgeWebber syndrome. A rare, but possible association. Rom J Morphol Embryol. 2007:48(2):171-5.

50. Widdess-Walsh P, Friedman NR. Left-sided facial nevus with contralateral leptomeningeal angiomatosis in a child with Sturge-Weber syndrome: case report. J Child Neurol. 2003;18(4):304-5.

51. Akabane N, Hamanaka T. Histopathological study of a case with glaucoma due to Sturge-Weber syndrome. Jpn J Ophthalmol. 2003;47(2):151-7.

52. Sakai H, Sakima N, Nakamura Y, Nakamura Y, Hayakawa K, Sawaguchi S. Ciliochoroidal effusion induced by topical latanoprost in a patient with sturge-weber syndrome. Jpn J Ophthalmol. 2002;46(5):553-5.

53. Akabane N, Hamanaka T. Histopathological study of a case with glaucoma due to Sturge-Weber syndrome. Nippon Ganka Gakkai Zasshi. 2001;105(10):705-10.

54. Mwinula JH, Sagawa T, Tawara A, Inomata H. Anterior chamber angle vascularization in Sturge-Weber syndrome. Report of a case. Graefes Arch Clin Exp Ophthalmol. 1994;232(7):387-91.

55. Akhtar F, Ali M, Zaheer N, Kausar A. Hypermetropia as a presentation of diffuse choroidal haemangioma in sturge-weber syndrome. J Coll Physicians Surg Pak. 2012;22(1):53-5.

56. Yuen NS, Wong IY. Congenital glaucoma from Sturge-Weber syndrome: a modified surgical approach. Korean J Ophthalmol. 2012;26(6):481-4.

57. Kaushik S, Kaur S, Pandav SS, Gupta A. Intractable choroidal effusion with exudative retinal detachment in Sturge-Weber syndrome. JAMA Ophthalmol. 2014;132(9):1143-4.

58. Cacciamani A, Scarinci F, Parravano M, Giorno P, Varano M. Choroidal thickness changes with photodynamic therapy for a diffuse choroidal hemangioma in Sturge-Weber syndrome. Int Ophthalmol. 2014;34(5):1131-5.

59. Tsipursky MS, Golchet PR, Jampol LM. Photodynamic therapy of choroidal hemangioma in sturge-weber syndrome, with a review of treatments for diffuse and circumscribed choroidal hemangiomas. Surv Ophthalmol. 2011; 56(1):68-85
60. Gambrelle J, Kivela T, Grange JD. Sturge-Weber syndrome: decrease in intraocular pressure after transpupillary thermotherapy for diffuse choroidal haemangioma. Acta Ophthalmol. 2011;89(2):190-3.

61. Knapp CM, Sarodia U, Woodruff GH. Central retinal vein occlusion associated with Sturge Weber syndrome. Eye. 2002;16(5):657-9.

62. Merritt $H$, Pfeiffer ML, Phillips ME, Richani K. Evisceration in patients with Sturge-Weber syndrome. Orbit. 2017;36(1):48-51.

63. Singh $P$, Singh S. Bilateral Sturge Weber syndrome- a rare case report. Nepal J Ophthalmol. 2013;5(1):129-32.

64. Chang L, Mruthyunjaya P, Rodriguez-Rosa RE, Freedman SF. Postoperative cilioretinal artery occlusion in Sturge Weber-associated glaucoma. J AAPOS. 2010;14(4):358-60.

65. Sihota R, Gupta V, Agarwal HC. Ultrasound biomicroscopic evaluation in Sturge Weber syndrome without glaucoma. Acta Ophthalmol Scand. 2003;81(4):408-9.

66. Kurtz SN, Melamed S, Blumenthal M. Cataract and intraocular lens implantation after remote trabeculectomy for Sturge-Weber syndrome. J Cataract Refract Surg. 1993;19(4):539-41.

67. Mosier MA, Smythe BA. Conjunctival photocoagulation in Sturge-Weber syndrome. Arch Ophthalmol. 1992;110(11):1530-1.

68. Verma L, Kumar A, Garg SP, Khosla PK. Iris neovascularization in SturgeWeber syndrome. Indian J Ophthalmol. 1991;39(2):82-3.

69. Yonekawa Y, MacDonald SM, Shildkrot Y, Mukai S. Standard fractionation low-dose proton radiotherapy for diffuse choroidal hemangiomas in pediatric Sturge-Weber syndrome. J AAPOS. 2013;17(3):318-22.

70. Cheung D, Grey R, Rennie I. Circumscribed choroidal haemangioma in a patient with Sturge Weber syndrome. Eye. 2000;14(Pt 2):238-40.

71. Ruby AJ, Jampol LM, Goldberg MF, Schroeder R, Anderson-Nelson S. Choroidal neovascularization associated with choroidal hemangiomas. Arch Ophthalmol. 1992;110(5):658-61.

72. Yin $X L$, Ye J, Yuan RD, Ji SX. A case of circumscribed choroidal hemangioma in Sturge-Weber syndrome in China. Int J Ophthalmol. 2011;4(2):210-1.

73. Althaus C, Sundmacher R. Combination therapy of circumscribed choroid hemangioma in contralateral Sturge-Weber syndrome with acetazolamide and laser coagulation. Klin Monbl Augenheilkd. 1996;208(4):239-42.

74. Gerwin BD, Char DH. Retinal vascular anomaly in Sturge-Weber syndrome. Retin Cases Brief Rep. 2011;5(3):245-8.

75. Shin GS, Demer JL. Retinal arteriovenous communications associated with features of the Sturge-Weber syndrome. Am J Ophthalmol. 1994;117(1):115-7.

76. Arora KS, Quigley HA, Comi AM, Miller RB, Jampel HD. Increased choroidal thickness in patients with Sturge-Weber syndrome. JAMA Ophthalmol. 2013;131(9):1216-9.

77. Abdolrahimzadeh S, Scavella V, Battaglia D, Recupero SM. Spectral domain optical coherence tomography of choroidal and outer retinal layer thickness in the Sturge Weber syndrome. Curr Eye Res. 2016;41(12):1614-7.

78. Alli SK, Adenuga OO, Ogbuagu MN, Velle LD, Akinyemi AO. Sturge-Weber syndrome in a 56 year old woman: a case report. Niger J Med. 2005;14(3):319-21.

79. Maruyama I, Ohguro H, Nakazawa M. A case of acute angle-closure glaucoma secondary to posterior scleritis in patient with Sturge-Weber syndrome. Jpn J Ophthalmol. 2002;46(1):74-7.

80. Chavala SH, Williamson JF. Bilateral exudative retinal detachments in SturgeWeber syndrome. Lancet. 2013;382(9888):259.

81. Moore DB, Reck SD, Chen PP. Angle closure glaucoma associated with ectopia lentis in a patient with Sturge-Weber syndrome. Eye. 2011;25(9):1235-6.

82. Sadda SR, Miller NR, Tamargo R, Wityk R. Bilateral optic neuropathy associated with diffuse cerebral angiomatosis in Sturge-Weber syndrome. J Neuroophthalmol. 2000;20(1):28-31.

83. Cibis GW, Tripathi RC, Tripathi BJ. Glaucoma in Sturge-Weber syndrome. Ophthalmology. 1984;91(9):1061-71.

84. Abdolrahimzadeh S, Fameli V, Mollo R, Contestabile MT, Perdicchi A, Recupero SM. Rare diseases leading to childhood glaucoma: epidemiology, pathophysiogenesis, and management. Biomed Res Int. 2015;2015:781294.

85. Rivera JC, Sapieha P, Joyal JS, Duhamel F, Shao Z, Sitaras N, Picard E, Zhou E, Lachapelle P, Chemtob S. Understanding retinopathy of prematurity: update on pathogenesis. Neonatology. 2011;100(4):343-53.

86. Patel SN, Klufas MA. Evidence to date: ranibizumab and its potential in the treatment of retinopathy of prematurity. Eye Brain. 2019;11:25-35.

\section{Publisher's Note}

Springer Nature remains neutral with regard to jurisdictional claims in published maps and institutional affiliations. 